\title{
Modernization Process in Iran: Historical Overview
}

\author{
Kamyab Shahriari (Corresponding Author) \\ Department of Government and Civilization Studies, Faculty of Human Ecology, University \\ Putra Malaysia (UPM) \\ Serdang, Selangor, Malaysia \\ E-mail: shahriarikamyab@gmail.com
}

Received: October 24, 2016 Accepted: January 25, 2017 Published: January 31, 2017

doi: 10.5296/jsss.v4i1.10206 URL: http://dx.doi.org/10.5296/jsss.v4i1.10206

\begin{abstract}
Modernization process in Iran began in $19^{\text {th }}$ century by Iranian officials like Abbas Mirza Ghaem Magham and Amir Kabir in order to change the traditional structure of government and replace it with a new and modern one. After the establishment of Pahlavi dynasty, the process of modernization continued by Reza Shah and Mohammad Reza Shah. After the victory of Islamic revolution of 1979 modernization didn't stop and continued until now. This paper examines the process of modernization in Iran from $19^{\text {th }}$ century up to the present. Research shows that although 100 years have passed since the victory of Iran's Constitutional Revolution and in spite of 150 years passing since modern political concepts introduced by intellectuals and inclusive struggles to establish modern political system, none of these have been incarnated in a tangible way. As a result, Iranian society is still in search of the rule of law, freedom and democracy, which had been introduced for the first time more than hundred years ago.
\end{abstract}

Keywords: Iran, Modernization, Reform, Constitution

\section{Introduction}

Modernization is a social change process which is rooted in modernity and aims to create developed societies. This process has been successfully experienced in the European countries where social changes have been fundamental, structural, integrated and systematic. The question about Iran is why despite more than a century of reform history, the country is not still a developed state. The pioneers of modernization in Iran were Abbas Mirza, Ghaem Magham Farahani and Amir Kabir. They undertook some measures to reform and modernize Iran. Indeed, the modernization of Iran was initiated by Abbas Mirza by means of military modernization. The second phase of modernization in Iran was undertaken by Ghaem Magham Farahani, who tried to bring elements of modernization to the bureaucracy. The 
third step of the modernization in Iran was undertaken by Amir Kabir, the Shah's chancellor. After the establishment of Pahlavi dynasty modernization program continued by Reza Shah and his son Mohammad Reza. After the victory of Islamic revolution of 1979 modernization didn't stop and continued until now. Although the content of reforms and modernization program in the Qajar and constitutional period to some extent differs from with the content of political modernization in the current period; but critical study of modernization program in Iran can contribute to understand the nature of political modernization process in Iran. Because political modernization process in Iran is still in a state of flux and has not reached political maturity. This article is to investigate features of modernization process in Iran from Qajar to the present to uncover the reasons behind the failure of modernization programs in Iran. Therefore, the Process of modernization divided into four periods. First period, modernization during Qajar era, Second period, modernization during Constitutional era. Third period, modernization during Pahlavi dynasty and Fourth period, modernization during Islamic Republic which each period will be discussed in detail.

\section{Modernization during the Qajar Era}

In fact, the modernization of Iran was initiated by Abbas Mirza by means of military modernization and also with activities such as reformation of Iran's army, utilize of new or modern weapons, sending students to Europe, inviting Europeans' industrialists and founding modern science and industries. In general, reformation of Abbas Mirza ${ }^{\mathrm{i}}$ can be summarized as inviting foreign consultants, sending of students and workers to foreign countries, establishment of some modern industrial institutes in Azerbaijan, translation of foreign books, and some other activities, which were followed by some ministers of Mohammad Shah and Naser-al-Din Shah. Also, coming as political and military delegations in Iran, as they brought reforms to Iran's military and also weapons production factory, mapping, and translation books. There were also the visits of some Armenian businesspersons to Iran. Several Iranians travelled to Europe and India to become familiar with modern education and sharing their information by translating books, and making Iranians familiar with some modern and new professions and knowledge (Gilani, 2009). The third Steps of modernization undertaken by Amir Kabir. Modernization and reformation during Amir Kabir's time can be named as revolution from above.

From among three models of modernization which were observed by Barrington Moore; conservative modernization (which happened in Germany and Japan), with implications for Iran too at that time. Amir Kabir was seeking a modern national government which should be strong and centralized (Adamiyyat, 2007). Establishing of such a government was a prerequisite for reforms. He wanted to establish a new form of monarchy and political system with emphasis on a central powerful government, a necessity to change the political power structure into a new structure in which people should have political and social rights, and even he wished to establish constitutional law. Amir Kabir was representative of development and intellectuality and can be regarded as the founder of reforms.

The historical importance of Amir Kabir is based on three factors: "first, his innovation in promotion of culture, science, and modern industries; second, protecting the national identity and political freedom of Iran against Western invasion; and third, political reform and fighting corruption" (Adamiyyat, 2007). At the beginning, he attempted to appoint qualified 
and competent people to political and military positions, then, worked on reforms in financial affairs, security of roads, military, economic, judiciary, and political reforms. Then, he established Dar al-Fonun to teach new and modern sciences to Iranian students.

Amir Kabir published the first daily newspaper in the name of Vaghayeh Etefaghiyeh. His high social status was because of these three reasons. First, he was representative of Iranian nationalism against European political and economic Colonialism; Second, he was representative of reforms in the political apparatus of government and also a reformer of civil rights; and Third, he was the propagator of modern Western science, culture and industries (Ajdani, 2007b). The fourth step of reforms and modernization undertaken by Sepahsalar, Prime Minister of Naser-al-Din Shah. He was influenced too much by Malkom Khan's idea. The reforms he started, involved different aspects such as reformation of governmental structure, modernization of the military and economic reforms. The essence of Sepahsalar era was the rule of law and observing of public social rights. The history of Iran's modern law was started with Sepahsalar's Ministry of Justice, and a new judiciary system was established by him and Mostashar ul - Dowla's struggle.

New laws were codified and the judiciary system somehow became independent. In addition, he worked on modernization of the military by creating a military council and organizing a cavalry system with the help of Austrian and Russian delegations. Regarding the daily newspaper, after Waqia-Etefaqia, which hed been stopped after Amir Kabir's murder, he published four more newspapers, namely, Waqia-Adlia, Nizami, Marikh va Vatan. Moreover, he established several new schools and also paid attention to the improvement of Dar al-Fonun, and built mosques, schools, and a Sepahsalar library (Shamim, 2005). Regarding economic reforms, he was especially concerned with changing commercial capital into industrial capital and, industrializing the country, establishing of banks and foreign investments (Amanat \& Vedjdani, 2012). After the dismissal of Sepahsalar in 1881, his political and economic reforms were interrupted and soon after the implementation of the modern judicial system was forgotten. Hence, Sepahsalar's period known as the period of modernism and legal government.

The first person who proposed a specific program for political modernization in Iran was Malkom Khan. He was the most distinguished and influential political thinker and activist in the period leading to the Constitutional Movement and formulated a comprehensive plan for the political modernization of Iran. Malkom Khan as reformist was the first Iranian scholar who attempted to struggle for law individual rights and freedom and rule of law. He was the first thinker who spoke about the necessity of establishment of Parliamentary Constitutional Monarchy and National Consultative Assembly. Constitutional Revolution of 1906 advanced based on the same model Malkom Khan illustrated in Qanun newspaper years ago (Adamiyyat, 2009; Ajdani, 2007a). The secret associations were affected by Malkom Khan's thought either in the form of organization or political thought. Secrets proclamations which printed and distributed in this period and calling for the people to rebellion and revolution either from political thoughts point of view or style of writing were influenced by Malkom Khan's thought (Abadian, 2009; Lambton, 1987).

Malkom Khan was the first political activist to establish an organized political party in the modern sense (Adamiyyat, 2009; Panahi, 2004). His actions and thoughts were the most 
important intellectual resources of the 1906 Constitutional Movement and the most important intellectuals of that period such as Akhundzadeh, Mirza Agha Khan Kermani, Talebof and Seyed Jamal al-Din Afghani were influenced by his ideas (Safari, 1998). Malkom Khan's greatest significance in the Iranian society lies in his quest for law and the establishment of strong centralized state. Malkom Khan presented many separate laws and several articles containing all the basic elements of a constitution in Iran.

\section{Modernization in the Constitutional Era}

After the failure of the reformists efforts from within the government by government's administrative personnel, many problems emerged in the country which remained unsolved. Bankruptcy, economic and social crises, poverty, dissatisfaction, and disappointment of the people from different levels of government. They demanded economic, social, and political reforms. With the failure of these reformist struggles, a powerful legal government with organized and powerful administration was not formed and the Qajar government remained inactive, weak and inadequate (Gheisari, 2010). In such a situation, there was confrontation of religion and society with government. Shiite scholars as an independent group separated from the government stood out as the most vocal and influential group among the social dissidents and opposition groups and turned against the government, taking over leadership of social, political movements and voiced their objections.

One of the most important movements that occurred at that time was the Tobacco Movement. This movement was against the granting of a concession to a British subject under the name of Barun Julious de Reuter, a concession, which had great implications (a monopoly for the sale of Persian tobacco and control over its production was granted for 50 years) in 1890 . Consequently, there were mass protests against the régime that were staged in major Iranian cities by the leadership of clergymen and finally a Fatwa was issued by the most important religious authority in Iran, the Marja'-I Taqlid. Mirza Hasan Shirazi, which declared the use of tobacco as illegal and tantamount to war against the Hidden Imam and made all society stand against the government (Rahbari, 2008b). The clergymen's struggle against the government was a big shock to the Qajar despotic government, which was forced to withdraw the concession. After the Tobacco Movement, Naser-al-Din Shah launched more political suppression. He opposed any kind of reformation and modernization. He continued expanding the Dar-al-Fonun, but prohibited the establishment of new schools. He declared Akhtar and Qanun, 2 famous newspapers, illegal and banned the importing of books and newspapers, which published abroad. The king also imposed a limit on the number of students being sent to Europe. From this time, onwards, the influence of Shiite clergymen increased considerably.

As Mozafar al-Din Shan succeeded to the throne and after the victory of the Constitutional Revolution in 1906, the wave of modernization reached a new peak. The establishment of the National Consultative Assembly, which became the political decision making center instead of the king and members of his court. In fact, it was a great achievement of the Constitutional Revolution (Ramezani, 2003). In addition, a significant and major reformative step was put to limit the powers of the king and the court. Meanwhile, efforts were made to establish the rule of law and national sovereignty through the activities of political. In fact, it was the turning point in the history of Iran in its transition from a traditional society to a modern one. It is 
considered the starting point for a series of basic and substantial reforms with the goals and objectives that were in line with modernization, development and rule of law.

It was an indication of the end of the traditional despotic period and the beginning of a modern absolute government. The first and second Constitutional Majlis attempted to establish a modern government through activities such as the abolition of the feudal system and aristocratic privileges and also by creating a modern bureaucracy through the enactment of a Court of Audit. And the creation of a state organization for the registration of deeds and properties and financial reforms, prediction of the creation of assembly and local associations, distributing of lords' properties, separation of religious and political duties from each other. However, active social forces in the system, especially clergymen, businesspersons, intellectuals and middle class people were unable to come together as a united body against the traditional elites, landlords, and their foreign supporters. Finally, they were defeated as conflict escalated among them.

The unity and cooperation between landlords and intellectuals defeated Mohammad Ali Shah, but led to the revival of despotism and failure of the modernization program in Iran. The expulsion of Morgan Shuster of America and a government coup against the second parliament were evidences of this. Overall, the Constitutional Movement suffered from lack of a compatible and consistent leadership (Maghsoudi, 2010). Constitutionalist clergymen did not have a clear image of political reforms. Even intellectuals had insufficient knowledge about political modernization and constitutional government as they only translated the constitution from European countries like Belgium and France and wanted to apply it in Iran without deep understanding of the real meaning of constitutionalism and democracy.

Secularism issues have remained unsolved to the present constitutional system and constitutional law in the old and backward social - economic structure of Iran were incompatible with the existing unproductive groups. The supplementary fundamental laws did not show any concern about changing the political structure. However, there was emphasis on the development of education, industries, freedom of the press and separation of powers. Repression of liberals and government coup against parliament indicated the ideological conflicts between the traditional and modern groups. Weakness of the intellectuals and middle class and the influence of landlords and traditional conservatives hindered basic changes in Iran society through constitutional reformation and modernization.

\section{Modernization during Pahlavi Dynasty}

Reza Shah initiated the first steps in the process towards a modern state in Iran in the 1920s. In 1925, he deposed the remnants of Qajar dynasty in Tehran and had himself appointed as Shah, thus resurrecting the ancient monarchial custom in Iran. He began his mission of modernization by reorganizing and updating the army and subduing the local tribes, ensuing that the central government held the sole monopoly over the legitimate use of coercion. Conscription ensured that young tribesmen were removed from their locale and scattered across Iran to town garrison far from their kin. In doing so, he was attempting to break traditional bond of local loyalties to the army and thus the national government (Nafisi, 2007). From 1930 onwards, Reza Shah continued to centralize power in the monarchy and the bureaucracy by creating a Minister of Finance, a National Bank and state monopoly over foreign trade. The government of Reza Shah was the first modern absolute government in 
Iran with important features such as, concentration and monopoly over using of resources and government power, formation of modern army, nationalism and emphasis on public interest.

Reza Shah by actualizing to unsuccessful modernization efforts of Abbas Mirza and Amir Kabir, in the first step, he established modern army and attempted to establish a powerful and centralized nation-state. With the National Bank established, Reza Shah introduced the modern fiscal technique of deficit financing, with government expenditures exceeding government revenues. He utilized these financial resources to continue to build the army and the modern bureaucratic state. He centralized the judiciary, and made the religious court subservient to civil courts thereby secularizing justice system. He omitted all references to sacred laws in the penal codes of 1939 and 1940 and forced clerics who wished to be employed as notaries to discard their turbans and assume civilian garb (Cronin, 2003). As well as his secularization and centralization ventures, Reza Shah engaged in numerous developmental strategies to stimulate the economy. He began improving irrigation methods in agriculture, introduced light mechanization on state lands and improved transport system of grain. Textile factories were established and other light industry was introduced to improve the economic situation in the country.

In terms of infrastructure development, Reza shah tended to prefer large and elaborate industrial project. A practice his son would adopt as Shah in the 1950s and later. He also pushed the development of highways and roads, to encourage transport of goods and to facilitate the continued centralization of his power. More than fourteen thousand miles of roads and highways, which he constructed, enabled the rapid transportation of government forces across the country to deal swiftly with potential tribal separatist tendencies and revolts (Foran, 2003). These tribes seem to understand this strategy, as numerous road crews and organizers were attacked or bombed in the construction process. The education system was also reformed or secularized with the establishment of state run primary and secondary schools and universities. Thus in addition to army, modern education system played major role for social mobilization and caused emergence of new generation of intellectuals and bureaucrats which played crucial role in the process of modernization. Despite these reforms, Shah did not attempt to alter land and agrarian relations as his son would after him. The reign of his son would witness rapid and widespread urbanization, the accelerated expansion of higher education and also speedy rates of industrial development and secularization of society. "Although Mohammad Reza would accelerate the modernization of Iran as well as fuel reactionary tendencies towards this transformation, it was Reza Shah who set initial process modernization in motion.

Modernization and reform although, gradually led to change in social and economic structures but according to Barrington Moore's theory on ways of modernization, was unsuccessful in the framework of conservative modernization and modernization from above. Reza Shah due to structural problem was unsuccessful to solve legitimacy, identity and distribution crises. Under the Reza Shah political freedom lost, activity of political parties was banned, the people deprived from freedom of speech, government put heavy censorship on press and also the parliament turned to a ceremonial institution, suffering the lack of independence which its representatives executed only Reza Shah's orders (Bashirieh, 2001). In fact, Reza Shah's government turned to a tyrant government that there was not any chance 
left for people for political participation. In fact, freedom, democracy, rule of law and participation, which were most important ideals and goals of Constitutional Revolution, during the reign of Reza Shah totally failed.

The occupation of Iran by the British and Soviets during the Second World War tested the rule of the new Shah. Reza Shah's son, Mohammad Reza assumed the position of Shah following the forced abdication of his father in 1941 for his sympathies towards Germany. The occupation of the war years resulted in the erosion of the new Shah's power, which the old Shah's had accumulated. More authority was disseminated to the Majlis and to the Prime Minister. Making the position of the Shah largely symbolic.

Following the withdrawal of soviet forces in 1946, the Shah slyly used his military to exert power in Azerbaijan and Kurdistan, by suppressing and disarming the rebels that the soviets had incited in their attempt to partition Iran. This action put the shah in the center of the Iranian political map, and he quickly began to restore the power of the monarchy after the loss of prestige, which the position had experienced since 1941. The occupation of 1940s witnessed tensions between Tehran and the occupying great powers regarding the issue of oil and oil concessions. A new nationalism emerged during this era. Mohammad Mossadeq, later to become Prime Minister, emerged as the chief representative of this nationalism, advocating the harnessing Iran's oil industry to aid Iranian development.

The Shah largely supported Mossadeq beliefs that oil revenue be increased to allow for modernization programs. Mossadeq become unreasonable, refusing outright to meet with American or British negotiators. By 1952, Eisenhower administration was becoming increasingly wary of Mossadeq, and the American began to believe that he needed to be removed (Kinzer, 2003). In 1953, a joint American-British intelligence operation was launched to remove Mossadeq. The end of the 1953 coup resulted in absolute dictatorship of the Shah's regime.

In 1960s, Kennedy administration began to pressure the Shah for land and social reforms to accompany his industrialization and modernization of economy. This pressure led to a number of reforms of 1963. The Shah visualized a wide range of changes that he called political, economic and social democracy and western social justice and self-sufficiency. He believed that it would be possible mix Western parliamentary principles and Persian monarchial traditions. It is evident that the Shah was attempting to introduce controlled mass mobilization without establishing any of the Western principles of political inclusion and participation, a factor detrimental to the smooth shift from traditional to modern society.

The Shah chose to continue these changes to achieve his own vision of social and economic progress without causing significant political change to undermine his position. He introduced "White Revolution to this end. the focus of this reforms was to transform Iran from traditional society, with poor, feudal roots and a decentralized state system, into prosperous, centralized and industrialized country" (Saikal, 1980, p. 82). The first of the Shah's amendments included land redistribution, the nationalization of forest, profit sharing among workers, the amendments of women's rights and the reform of electoral laws. The early of 1970s witnessed a broadening of these changes. Each of these ventures were designed to industrialized Iran quickly and to increase power and centralization of the national government. However, these changes were not intended to modernize on a political 
level. The history of Persian rule has largely been one of nomadic dynasties that relied on violence and repression to secure their rule. The Pahlavi Shahs continued this practice of political repression. Following the Mossadeq coup in 1953, the Shah intensified his effort to centralize his rule and fiercely repress opposition movements. He banned all forms of political organizations and imposed tight censorship on the media. The Majlis became the rubber stamp for the Shah's policies as it was composed of elected men chosen by the regime for their loyalty to the Shah. A two-party system was introduced, with one party always assume ruling party and the other always constituting opposition. These were controlled by the Shah as well and political activity beyond these parties was non-existent. The oppositional leaders such as Ayatollah Khomeini were exiled.

A result of Shah's purging of all the regime's opposition leaders, was that he essentially operated within a traditional pattern of rule that epitomized the personification of politics, rather than institutionalization of politics (Hoveyda, 2003). The Shah did not have the benefit of those within his ruling circle to tell him he was wrong, or that his policies be ineffective. Huntington uses the phrase 'safety valves' to describe those institutions for interest articulation such as unconstrained trade unions, pressure groups and elected and independent legislatures. The Shah prevented the articulation of grievances by the populace, and as a result, opposition movements were forced to seek other avenues to air grievances. The absence of these safety valves in Iran contributed to mass frustration among the populace and unrest ensued among these groups.

The 1959 Labor Law established that the only labor and trade unions permitted to exist in Iran would be those that were organized by the Ministry of Labor. These meant that the Shah held influence over all the actions of these groups, and as such dissention would not be permitted (Tolooi, 2009). Any attempt on the part of these unions to strike was often fiercely dealt with by police, who often fired on striking workers. While these unions did have input into labor conditions, they did not possess the right to strike. They existed mainly to enforce labor discipline, and often had connections with Savak (secret police force of the Shah). These unions allowed a partial mobilization to support the Shah, but did not allow opposition of the regime. They allowed unions members to become politically aware only if they supported the Shah. It seemed dangerous for the Shah to permit only partial mobilization of the working class in this form, as it is likely that those who opposed him would become politically mobilized as well. He clearly expected the populace to behave like traditional subjects, and to support him or remain silent while modernity was occurring all around them. By closing off all avenues of dissent, the Shah was channeling all the grievances of the populace towards himself. Traditional monarchial governments have relied on three pillars of power to secure their rule; the army or police, the bureaucracy and religion (Fardoost, 2009). The Shah's power base, however, rested in his bureaucracy and his military and Savak, while alienating the religious leaders and their support for his regime. He ensured that this bureaucratic and patronage appointments relied on him to keep them in power. The Pahlavi state defended the interests of the upper strata of society, and as a result, they were loyal to him until the revolution. The military and Savak were used to crush and demoralize opposition within the regime, as well as to control public opinion.

The effectiveness of Savak in crushing that opposition was stifled was absolute, and as result, 
opposition within the regime had minimal opportunity to organize until 1978 when the Shah ordered the Savak to become lenient and permit some freedom of expression. It was for this reason when the revolution did come in 1978, it would be the religious leaders who were the most prepared and organized to mobilize the support of the populace (Milani, 2011).

In fact, the absence of political institutions to facilitate greater participation in the regime as well as forums such as independent interest groups and labor unions caused the pressure of political opposition to fester. The frustrations of the populace, prohibited from being expressed in legal, representative institutions would find an outlet in traditional Islamic institutions and religious leaders. When revolution began in 1979, it took the form of a religious inspired uprising that caused the abdication of the Shah and the establishment of Theocratic regime.

\section{Modernization and Reformation in the Islamic Republic}

Although the Islamic Republic of Iran was established after the Islamic Revolution in 1979, gradually it became fundamentally a different phenomenon, either intellectually or in terms of social status. Three main sights of resistances and democracy discourse in contemporary Iran included, First, constitutionalism against the Qajar's Patrimonial system; Second, National Movement of Mossadeq and Islamic Revolution against Pahlavi modernism, and Third, civil society movement against the ideological traditionalism in the Islamic Republic after 1979. The Islamic Revolution was a response to the modernization crisis, and with the intention of creating a secure shelter during the turbulent process of modernization, through rule of law.

After the Islamic Revolution, important steps were taken in terms of the formation of modern and electoral political institutions, strengthening of democratic and pluralist culture and sphere but more important steps have been taken in traditionalism. Many past efforts at reform, especially in relation to the establishment of a national, modern and democratic state had become sterile, and failed. The Islamic Republic, instead of doing fundamental changes in the socio-economic structures, and political modernization in line with the objectives of the Revolution fell into the trap of fundamentalism. Iran's political system, according to Constitutional Law is based on three legitimate sources: charismatic legitimacy, which emerged in Ayatollah Khomeini's lifetime Vlayate Faqih (Guardianship of the jurist) a brand of authority and legitimacy dominant from 1979 - 1989. The second was traditional and religious authority, with some of the most important governmental positions run by clergymen, and was dominant from 1989 to 1997 . Third is legal democratic authority with parliament and the presidential administration being its most important aspects, which was dominant from 1997 up to the present. Thus, the political history of Iran after the Islamic Revolution can be divided into three stages: the charismatic period, the oligarchy period and finally, rule of law.

Modernization during the Islamic Republic period can be divided into four phases: the first phase is during Ayatollah Khomeini's lifetime, Iran-Iraq war from September 22, 1980 August 20, 1988. Second phase coincided with the end of the war and months before the death of Ayatollah Khomeini (June 2, 1989). The third phase was the reform period by president Khatami from 1997 to 2004, and with the fourth phase, encompassing the failure of reformists and the victory of fundamentalists and presidency of Mahmoud Ahmadi Nejad. These four phases will be discussed in detail. 
In the first period, the interim government of Iran was established and headed by Mehdi Bazargan; the government consisted of national and religious figures with independent liberal attitude, pro-democracy and anti-theocracy. From the beginning of the establishment of the Islamic Republic parallel institutions established, as revolutionary and Islamic institutions made the situation problematic for the interim government, leading to its failure and inactivity (Movassaghi, 2008). Islamic radical groups gradually further weakened the interim government by controlling the Council of the Islamic Revolution and wide institutionalization with an ideological approach and finally, by occupying the American embassy which forced the interim government to resign. The failure of the interim government is considered as the important step that limited the competition sphere and political participation. As a result, the type of political participation and activities completely changed and politics in Iran took on a populist nature.

As a result, political activities of political parties banned and only Islamic Republican party was allowed to be active. It should be mentioned that some factors caused this situation including, confrontation of Bani Sadr (the first President of the Islamic Republic of Iran) against Rejai, the Prime Minister and members of the Islamic Consultative Assembly and Islamic Republic Party, the beginning of armed activities of the Mujahedin Khalq in 1981 and the Iraq invasion of Iran (Movassaghi, 2009). Indeed, all of these events had a determinant role in the closing of the democratic political sphere heralded the beginning of the wave of totalitarianism.

The most important ideological conflicts happened among liberal groups especially Nehzat -e Azadi Iran (Freedom Movement of Iran) and fundamentalists on Constitutional Law and Velayat -e Fagih (Guardianship of Jurist). Unlike the suggestion of the interim government based on the establishment of a constituent assembly, the Supreme Leader and Council of the Islamic Revolution supported the formation of the Assembly of Experts of the Leadership. During that time, with the approval of constitutional law based on Velayte Faqih, the nature of the Islamic Republic was determined. In fact, the system established after the Islamic Republic was based on charismatic personality and features of Ayatollah Khomeini. Though with approval of the constitution of the Islamic Republic, charismatic power and traditional power merged in the institution of Velayat -e Faqih, but Ayatollah Khomeini was the core of politics in Iran (Asadi, 2009). In the cases of serious disputes among revolutionary groups he was the adjudicator; the founder of some of the most important political and social institutions. In the shadow of the leader, a kind of clerical oligarchy formed. In other words, he was at the top of all legal and bureaucratic institutions.

The second phase of modernization started in 1989 after Ayatollah Khomeini's passing and with the beginning of the Rafsanjani presidency, during which the priorities were economic development due to damages caused by the war, which also brought serious problems to Iranian society. The new ways adopted by Rafsanjani included: First: changing of Iranian society from a closed society to an open one; Second: flexibility in religious and traditional patterns; Third: using of experts and adopting new methods instead of old and unsuccessful methods, and Fourth: reducing state control over the economy (Asadi, 2009).

One of the most important actions done in this period was changing and amending the constitution to increase the powers of the president. In addition, the Rafsanjani government 
adopted pragmatism and moderation in its domestic and foreign policies. Prioritized economic development, and in the case of foreign policy adopted a realistic approach and détente toward the normalization of relations with the West, Europe and the Arab world, especially Saudi Arabia (Brumberg, 2001). In this period, the fundamentalists or traditional conservatives turned to a united and coherent oligarchy, which by controlling the main governmental institutions such as the judiciary and the Guardian Council of the Constitution, opposed Rafsanjani's policies. Thus, as the power of conservatives escalated, Rafsanjani was forced to abandon his reform policies in his second presidential term, and under the pressure of the conservatives he was forced to concede some important ministries to them.

In the political and cultural domain, especially with the activation of pressure groups and fundamentalists and the interference of organizations, which were not under the control of the government, political and civil freedoms were curtailed. All of these factors led to the failure of the political modernization process and undermined the democratic foundations of the system. Monopolization and irresponsibility of conservatives caused Rafsanjani's tendency to reformists.

The Third period of modernization started from 1997 with the victory of the reformists and Khatami's presidency which known as the period of political reforms. It is counted as a new chapter in the history of Iran. The victory of the reformists confirmed the existence of a deep crisis of political participation in the political system of Iran. The victory of the reformists resulted in strengthening democratic foundations of the political system and the return to the fundamental ideals of the revolution, which was based on elimination of despotism, consolidation of the foundation of the Constitution, limitation of power, consolidation of parliamentary and civil institutions (Pazhoohesh, 2011).

Khatami in the first term of his presidency proposed a new discourse based on political participation, expansion of political and civil freedom, rule of law and emphasis on democracy and detente in foreign policy. In this sphere the number of reformist newspapers escalated, which featured issues such as rationality, rule of law, democracy, freedom of speech, human rights, nationalism and citizenship, which had entered Iranian political culture and had a great effect on it. Khatami's most important achievement was to help spread the idea of democracy. In this period, many books were published and people could talk more freely on issues such as rule of law, despotism and Velayat -e Faqih. People could protest and criticize the government more (Bashirieh, 2009).

The publication of books and newspapers from 1989 onwards, which was a major force instead of political parties after Berlin Conference in 1999, was interrupted and the wave of pressure and harassments of journalists was begun. By strengthening the democratic discourse and detente in foreign policy and introducing the idea of dialogue among civilizations, Iran's relations with Arab countries and especially Saudi Arabia improved which led to their closer cooperation in OPEC. In fact, the reform movement accompany with Khatami's democratic discourse was a reformist movement with massive participation of all spectra of society such as intellectuals, youngsters, middle class, and women which was in line with the Constitutional Movement of 1906, Mossadeq's National Movement and the ideals of the Islamic Revolution to restore democracy. But this movement was unable to meet people's desires through a clear strategy and therefore, in this period the political process to 
run major reforms, failed (Vahdati, 2012). The separation of most moderate groups (supporters of Rafsanjani) from reformists undermined them.

Khatami's government, due to weakness and internal rifts and disputes was unable to enforce the law and to meet the freedom and political demands of the people. In the first term of his presidency, Khatami's priority was political development and freedom and did not pay too much attention to economic problems. On the other hand, fundamentalist groups exploited these weaknesses and inefficiencies. Fundamentalists at various pressure levers, attempted to sabotage Khatami's government by actions such as interpellation of cabinet ministers, shutting down the reformist newspapers and arresting of political activists. Duality between President and Prime Minister, which during the lifetime of Ayatollah Khomeini had been solved, in this period turned to duality between leader and president and caused inconsistency among appointed and elected officials (Alikhani, 2008). This inconsistency led to dual sovereignty inside the system and brought about severe weaknesses for Khatami's government. In such a situation in his second term, Khatami (2001-2005) deviated from his former ideals, cooperated more with conservatives, and attempted to maintain the status quo by adopting policies that were more conservative. The Fourth period of modernization started after the victory of Ahmadi Nejad (2005-2013), following his victory over the reformists and moderates to become the Iranian President. In fact, Ahmadi Nejad's victory meant the failure of reforms. In this period, political development gave away and was forgotten; some political organizations merged with each other which negatively impacted their efficiency and turned them into symbolic institutions. Political parties which acted more freely during Khatami's presidency, in this period found their activities limited and even prohibited, and some of their leaders imprisoned (Jafari, 2014).

In this period, the press was under pressure imposed by the government and many media companies and publications ceased to exist. The number of newspapers, which escalated during Khatami's presidency, was drastically reduced. In this period, issues such as political modernization and reforms were forgotten and in the case of foreign policy, tension between Iran and other countries, especially the Arab countries began to mount again, which led to the isolation of Iran. During the presidency of Ahmadi Nejad, fundamentalism in Iran's domestic and foreign policy escalated. Iran's nuclear program was another reason, which made Iran more isolated in the world and led the Security Council of United Nations to issue a resolution against Iran. These revolutions led to heavy sanctions imposed by the UN and great powers on Iran, which not only led to further isolation of Iran but also uncontrolled inflation and devaluation of Iran's currency which destroyed the country's economy.

\section{Conclusion}

Political modernization in the transitional society of Iran that underwent a long period of despotic governments is of utmost importance. Because Iran society due to the defeat in war with Russia in the first two decades of eighteenth century tended to political modernization and advocated of constitutional government. Constitutional Revolution of 1906 was the outcome of the efforts of Iran society to meet that demands. But the revolution and its goal which was political modernization failed, and consolidation of despotic government was the outcome of this failure. This was subsequently followed by the Islamic Revolution of 1979, which held somewhat the same goals as Constitutional Revolution. It too suffered the same 


\section{I Macrothink}

Journal of Social Science Studies

ISSN 2329-9150

2017, Vol. 4, No. 1

fate. Although 100 years have passed since the victory of Iran's Constitutional Revolution and in spite of 150 years passing since Iranian intellectuals introduced modern political concepts and inclusive struggles to establish modern political system, none of these have been incarnated in a tangible way. As a result, Iranian society is still in search of the rule of law, freedom and democracy, which had been introduced for the first time more than hundred years ago.

\section{References}

Abadian, H. (2009). The Crisis of Awareness and Genesis of Intellectualism in Iran. Tehran: Kavir.

Adamiyyat, F. (2007). Amir Kabir and Iran. Tehran: Kharazmi.

Adamiyyat, F. (2009). Thought of Freedom and Prelude of Constitutional Movement. Tehran: Kharazmi.

Ajdani, L. (2007a). Iranian Intellectuals in Constitutional Era. Tehran: Akhtaran.

Alikhani, A. (2008). Mosharekate Siasi. Tehran: Safir.

Amanat, A., \& Vedjdani, F. (2012). Iran Facing Others: Identity Boundaries in a Historical Perspective: Palgrave Macmilan.

Asadi, J. (2009). The Islamic Republic and Political Participation. Tehran: Arghavan.

Bashirieh, H. (2001). Obtacles to Political Development in Iran. Tehran: Gaame No.

Bashirieh, H. (2009). State, Civil Society and Political Development Discourses. Tehran: Nashre Tablighate Eslami.

Bigdeli, A. (2006). Political and Social History of Iran. Tehran: University of Tehran.

Brumberg, D. (2001). The Struggle for Reform in Iran. Chicago: University of Chicago Press.

Cronin, S. (2003). The Making of Modern Iran; State and Society under Reza Shah, (M. Saghebfar, Trans.). Tehran: Jami.

Fardoost, H. (2009). Rise and Fall of Pahlavi Dynasty. Tehran: Eettelaat.

Foran, J. (2003). Fragile Resistance (A. Tadayyon, Trans.). Tehran: Rasa.

Gheisari, A. (2010). The Iranian Intellectuals in Twenteeth Centuey. Tehran: Hermes.

Gilani, A. (2009). Iran during Constitutiona Era. Tehran: Shoor Afarin.

Hoveyda, F. (2003). The Shah and the Ayatollah: Iranian Mythology and Islamic Revolution: Westport: Praeger.

Kinzer, S. (2003). All the Shah's Men. New Jersey: John wiley \& Sons.

Lambton, A. K. S. (1987). Qajar Persia. Texas: University of Texas.

Maghsoudi, b. (2010). Iran in Ninetheenth Century. Thran: Akhtaran.

Milani, A. (2011). The Shah: Palgrave Macmillan.

Movassaghi, A. (2008). Religion, Society and State in Iran. Tehran: Moasse ye Tahghighat va Toseye Oloome Ensani.

Movassaghi, A. (2009). Modernization and Reformation in Iran. Tehran: Ghomes.

Nafisi, S. (2007). History of Political and Social Development in Iran . Tehran: Tarhe No.

Panahi, A. (2004). Iranian Intelectuals and the West. Tehran: Moasseseye Ghadre Velayat. 
Rahbari, M. (2008b). Failed Constitution. Tehran: Kavir.

Ramezani, H. (2003). Roshanfekrane Irani Dar Asre Ghajar. Tehran: Agah.

Safari, M. A. (1998). Mashrooteh Sazan Tehran: Elm.

Saikal, A. (1980). The Rise and the Fall of the Shah: Princeton University Press.

Shamim, A. (2005). Iran during Qajar Era. Tehran: Elmi.

Tolooi, M. (2009). Palyers of Pahlavi Era. Tehran: Nashre Elm.

\section{Copyright Disclaimer}

Copyright for this article is retained by the author(s), with first publication rights granted to the journal.

This is an open-access article distributed under the terms and conditions of the Creative Commons Attribution license (http://creativecommons.org/licenses/by/3.0/). 